\title{
Chemical and physical composition of grain-type and food-type soybean for food processing
}

\author{
Josemeyre Bonifácio da Silva(1), Mercedes Concórdia Carrão-Panizzi(2) and Sandra Helena Prudêncio(1)
}

\begin{abstract}
(1)Universidade Estadual de Londrina, Departamento de Ciência de Alimentos, Campus Universitário, Caixa Postal 6001, CEP 86051-990 Londrina, PR, Brazil. E-mail: josi@cnpso.embrapa.br, sandrah@uel.br ${ }^{(2)}$ Embrapa Soja, Caixa Postal 231, CEP 86001-970 Londrina, PR, Brazil. E-mail: mercerdes@cnpso.embrapa.br
\end{abstract}

\begin{abstract}
The objective of this work was to evaluate the chemical and physical characteristics of grains of soybean (Glycine max) cultivars for food processing. The soybean cultivars evaluated were: grain-type BRS 133 and BRS 258; food-type - BRS 213 (null lipoxygenases), BRS 267 (vegetable-type) and BRS 216 (small grain size). BRS 267 and BRS 216 cultivars showed higher protein content, indicating that they could promote superior nutritional value. BRS 213 cultivar showed the lowest lipoxygenase activity, and BRS 267, the lowest hexanal content. These characteristics can improve soyfood flavor. After cooking, BRS 267 cultivar grains presented a higher content of aglycones (more biologically active form of isoflavones) and oleic acid, which makes it proper for functional foods and with better stability for processing, and also showed high content of fructose, glutamic acid and alanine, compounds related to the soybean mild flavor. Because of its large grain size, BRS 267 is suitable for tofu and edamame, while small-grain-sized BRS 216 is good for natto and for soybean sprouts production. BRS 216 and BRS 213 cultivars presented shorter cooking time, which may be effective for reducing processing costs.
\end{abstract}

Index terms: Glycine max, amino acids, fatty acids, hexanal, isoflavones, lipoxygenases, sugars.

\section{Composição química e física de soja tipo grão e tipo alimento para o processamento de alimentos}

Resumo - O objetivo deste trabalho foi avaliar as características químicas e físicas de grãos de cultivares de soja (Glycine max) para o processamento de alimentos. As cultivares avaliadas foram: tipo grão - BRS 133 e BRS 258; tipo alimento - BRS 213 (desprovida de lipoxigenases), BRS 267 (tipo hortaliça) e BRS 216 (tamanho de grão pequeno). As cultivares BRS 216 e BRS 267 apresentaram maior teor de proteínas e poderiam promover valor nutricional superior. A cultivar BRS 213 apresentou a menor atividade de lipoxigenases e a BRS 267, o menor teor de hexanal. Essas características podem melhorar o sabor dos alimentos. Com o cozimento, os grãos da cultivar BRS 267 apresentaram maior teor de agliconas (forma biologicamente mais ativa das isoflavonas) e de ácido oleico, o que a torna adequada para alimentos funcionais e com melhor estabilidade para processamento, além de maior teor de frutose, ácido glutâmico e alanina, compostos relacionados ao sabor suave da soja. A cultivar BRS 267, com maior tamanho de grãos, é adequada para tofu e edamame, e a BRS 216, com menor tamanho, é apropriada para natto e para produção de brotos de soja. As cultivares BRS 216 e BRS 213 apresentaram menor tempo de cozimento, o que pode ser eficaz para reduzir os custos do processamento.

Termos para indexação: Glycine max, aminoácidos, ácidos graxos, hexanal, isoflavonas, lipoxigenases, açúcares.

\section{Introduction}

Soy processing industries select raw material based on weight, moisture, impurities and grain damage. Differences in chemical and physical properties of soybean cultivars are not taken into consideration in soyfood processing. Information on these characteristics could help food industries obtain products with better functional, nutritional and sensory qualities with greater cost-benefits (Sbardelotto \& Leandro, 2008).
According to their different uses, soybean cultivars are classified as grain-type, which are conventional soybeans for oil and animal feeding, and food-type, which are those for human consumption in fermented foods (misso, tempeh and natto) and non-fermented foods (tofu, soy flour and soy milk) (Liu, 1999). Therefore, soybean cultivars for human consumption should present special chemical, physical and sensory characteristics.

Protein, fatty acids (oleic, linoleic and linolenic) and sugar contents as well as absence of lipoxygenase 
enzymes, grain size, clear hilum and cooking time are some of the characteristics that can be modified through genetic breeding in order to obtain suitable soybean cultivars for human consumption. These characteristics must be confirmed by chemical, physical and sensory analysis (Carrão-Panizzi, 2000; Meneguce et al., 2005).

Soybean is an important source of high-quality protein. Soybean cultivars with high protein content allow the production of foods with superior nutritional value and yield, such as soy milk and tofu (Liu, 1999; Moraes et al., 2006). Low concentration of polyunsaturated linoleic and linolenic fatty acids and higher oleic acid content increase oil stability and prevent oxidation and production of off-flavors during food processing (Fehr, 2007). Genetic elimination of lipoxygenase enzymes can improve the flavor of soy products by reducing the formation of the hexanal compound associated with the beany flavor (Furuta et al., 1996).

Isoflavones are compounds found in soybean that have estrogenic, antifungal, antioxidant and antitumor properties. Soybean grains present different forms of isoflavones such as glucosides, acetylglucosides, malonyl-glucosides and aglycones. The latter form, composed by daidzein and genistein, has greater biological activity. Therefore, soybean cultivars with high content of isoflavone aglycones can increase functional properties of soy foods (Aldin et al., 2006).

In soybean grains, the amount of sucrose, the main carbohydrate, can range from 15 to $102 \mathrm{~g} \mathrm{~kg}^{-1}$, while glucose is found in trace quantities (Liu, 1999). The oligosaccharide content can vary from 1 to $21 \mathrm{~g} \mathrm{~kg}^{-1}$ for raffinose and from 14 to $67 \mathrm{~g} \mathrm{~kg}^{-1}$ for stachyose. These saccharides can be associated with flatulence problems in monogastric animals, although in humans they can also contribute to the growth of beneficial colon bacteria (Tomomatsu, 1994). Vegetable-type soybean cultivars present milder and sweeter flavor than conventional cultivars (Masuda, 1991), a consequence of the higher content of sucrose and of glutamic acid and alanine amino acids.

Soybean grain size can be an important quality characteristic for soyfood depending on the type of utilization. Small grain sizes (weight of 100 grains of 7-10 g) are more suitable for natto and soybean sprouts, whereas large grain sizes (weight of 100 grains of 20-30 g) are recommended for tofu or edamame.
Water absorption capacity and shorter cooking time are other factors related to the reduction of costs in processing (Meneguce et al., 2005).

There is little information about the chemical, physical and sensory characteristics of food-type soybean cultivars that could help soy food industries to properly process high-quality products for human consumption.

The objective of this work was to evaluate chemical and physical characteristics of grains of soybean cultivars for food processing.

\section{Materials and Methods}

The soybean cultivars evaluated were: grain-type - BRS 133 and BRS 258; food-type - BRS 213 (null lipoxygenases), BRS 267 (vegetable-type) and BRS 216 (small grain size). The grains were produced in the 2005/2006 growing season and were supplied by Embrapa Soja, located in Londrina, Paraná, Brazil.

The chemical analyses were carried out on both raw and cooked grains. The cooking process inactivates lipoxygenase enzymes, improves flavor, and reduces anti-nutritional factors, improving protein digestibility. For cooking treatments, the grains were soaked in distilled water for 16 hours at room temperature $\left(25^{\circ} \mathrm{C}\right)$, cooked in an autoclave at $121^{\circ} \mathrm{C}$ for five min, dried in a ventilated chamber at $50^{\circ} \mathrm{C}$ for 72 hours and then ground in a knife grinder (100 mesh) (TE 631, Tecnal, Brazil).

The protein, lipid and carbohydrate contents were determined according to a method developed by Instituto Adolfo Lutz (2005). Lipoxygenase activity was determined using a spectrophotometer (3000 Series, Cecil Instruments, England) according to the Axerold et al. (1981) method. In a glass cuvette, $5 \mu \mathrm{L}$ of extract (soybean sample) and $50 \mu \mathrm{L}$ of linoleate stock solution were mixed with $2 \mathrm{~mL}$ of sodium phosphate buffer (50 $\left.\mathrm{mmol} \mathrm{L}^{-1}, \mathrm{pH} 6\right)$. The lipoxygenase activity was read by measuring the increased absorbance at $234 \mathrm{~nm}$ over $1 \mathrm{~min}$.

The hexanal and fatty acids contents were determined by gas chromatography according to the Min et al. (2005) and Rayford et al. (1994) methods, respectively. The gas chromatograph (HP 6890, Hewlett Packard, USA) was equipped with a silicone capillary column (30 m length, $0.32 \mathrm{~mm}$ diameter and $0.2 \mu \mathrm{m}$ thick film) (SP 2340, Supelco, Sigma-Aldrich, 
USA). The hexanal analysis was performed with an initial column temperature of $45^{\circ} \mathrm{C}$ and the temperature of the injector was kept constant at $150^{\circ} \mathrm{C}$ throughout the analysis. A flame ionization detector (HP 6890, Hewlett Packard, USA) with temperature programmed at $220^{\circ} \mathrm{C}$ was used for detecting the constituents. The carrier gas (ultrapure hydrogen) flow was set to $20 \mathrm{~mL} \mathrm{~min}{ }^{-1}$. The analysis of fatty acids was conducted by isothermal chromatography at $190^{\circ} \mathrm{C}$. Detection was performed using a flame ionization detector (HP 6890, Hewlett Packard, USA) with temperature programmed to $300^{\circ} \mathrm{C}$, with the injector at $250^{\circ} \mathrm{C}$ throughout the analysis. The gas flow settings were: $40 \mathrm{~mL} \mathrm{~min}^{-1}$ for helium, $40 \mathrm{~mL} \mathrm{~min}{ }^{-1}$ for hydrogen and $450 \mathrm{~mL} \mathrm{~min}^{-1}$ for synthetic air.

The isoflavones were extracted according to Carrão-Panizzi et al. (2002) and quantified by Berhow (2002) method using a liquid chromatograph (model 2690, Waters, USA). The separation was carried out in a C18 reverse type column (model YMC-Pack ODS-AM, YMC Europe Gmbh, Germany) (S-5 mm, $120 \mathrm{~A}, 250 \mathrm{~mm}$ long $\mathrm{x} 4.6 \mathrm{~mm}$ diameter), and a photodiode array detector (model 996, Waters, EUA) was used to detect the isoflavones at a $254 \mathrm{~nm}$ wavelength. A linear binary gradient system with methanol, trifluoroacetic acid and ultrapure deionized water was used for separation. The initial gradient was $20 \%$, reached $90 \%$ at $35 \mathrm{~min}$ and returned to $20 \%$ at $40 \mathrm{~min}$. The mobile phase flow rate was of $1 \mathrm{~mL} \mathrm{m^{-1 }}$, and the temperature during the race was kept constant at $25^{\circ} \mathrm{C}$.

Sugar contents of the samples was determined following the protocol described by Masuda et al. (1996), using an ionic exchange chromatograph (ED 50, Dionex Bio LC, USA) equipped with an amperometric detector, $\mathrm{AgCl}$ electrode (ED 50, Dionex Bio LC, USA), amperometric gold cell and sample self-injector. A CarboPac PA 10 column $(250 \mathrm{~mm}$ length $\mathrm{x} 4 \mathrm{~mm}$ internal diameter and $5 \mu \mathrm{m}$ particles) was used to separate the sugars. The analyses were conducted adopting the system isocratic analysis and a $50 \mathrm{mmol} \mathrm{L}^{-1} \mathrm{NaOH}$ solution as mobile phase at a $1.0 \mathrm{~mL} \mathrm{~min}^{-1}$ flow rate at $25^{\circ} \mathrm{C}$.

The composition of amino acids was determined only in cooked samples by the technique of Spackman et al. (1958) in an ionic exchange chromatograph (ED 50, Dionex Bio LC, USA) using the automatic recording apparatus according to Alonzo \& Hirs (1968). The column temperature was initially programmed to $55^{\circ} \mathrm{C}$ and subsequently raised to $75^{\circ} \mathrm{C}$ throughout the analysis. The sodium citrate buffer elution solution's $\mathrm{pH}$ began at 3.25 and was increased to 4.25 and 5.28 by the end of the analysis.

The average raw grain size was the weight of 100 grains. The difference in grain weight was calculated as water absorption percentage and measured before and after soaking in distilled water for 16 hours at room temperature $\left(25^{\circ} \mathrm{C}\right)$. The cooking time was measured using a Mattson equipment (model 3020, Mattson Technology, Inc., USA), according to Meneguce et al. (2005). After cooking (autoclave at $120^{\circ} \mathrm{C}$ for five minutes), the quantity of grains with lost seedcoats and broken cotyledons were counted to measure sample integrity.

A completely randomized experimental design was used in factorial arrangement: five soybean cultivars and two preparation methods (raw and cooked grains), with three replicates. The data were submitted to analysis of variance (ANOVA) and the means were compared by Tukey's test, at $5 \%$ probability using the SAS-Statistical Analysis System scientific package (SAS Institute, 2001). The Sanest (Zonta et al., 1982) analysis system was used for the partitioning of treatments.

\section{Results and Discussion}

The highest protein content in raw grains was observed in vegetable-type soybean cultivar BRS 267 (Table 1).

Table 1. Chemical composition $\left(\mathrm{g} \mathrm{kg}^{-1}\right.$ dry weight) of raw and cooked soybean grains ${ }^{(1)}$.

\begin{tabular}{|c|c|c|c|c|c|c|}
\hline \multirow[t]{2}{*}{ Cultivar } & \multicolumn{2}{|c|}{ Protein } & \multicolumn{2}{|c|}{ Lipids } & \multicolumn{2}{|c|}{ Carbohydrates } \\
\hline & Raw & Cooked & Raw & Cooked & Raw & Cooked \\
\hline BRS 213 & $401.20 \mathrm{bB}$ & $432.36 \mathrm{bcA}$ & $194.83 \mathrm{aB}$ & $237.23 \mathrm{bA}$ & $343.80 \mathrm{aA}$ & $291.20 \mathrm{abB}$ \\
\hline BRS 216 & $412.69 \mathrm{bB}$ & $471.83 \mathrm{aA}$ & $188.86 \mathrm{aB}$ & $222.76 \mathrm{bA}$ & $337.69 \mathrm{abA}$ & $270.19 \mathrm{bcB}$ \\
\hline BRS 267 & $444.90 \mathrm{aB}$ & $469.13 \mathrm{aA}$ & $181.56 \mathrm{aA}$ & $191.96 \mathrm{cA}$ & 311.76abA & $300.00 \mathrm{abA}$ \\
\hline BRS 258 & $426.96 \mathrm{bA}$ & $447.83 \mathrm{abA}$ & $198.69 \mathrm{aB}$ & $266.67 \mathrm{aA}$ & $306.46 \mathrm{bA}$ & $248.03 \mathrm{cB}$ \\
\hline BRS 133 & $406.59 \mathrm{bA}$ & $408.80 \mathrm{cA}$ & $199.76 \mathrm{aB}$ & $233.56 \mathrm{bA}$ & $333.43 \mathrm{abA}$ & $320.53 \mathrm{aA}$ \\
\hline CV (\%) & \multicolumn{2}{|c|}{2.92} & \multicolumn{2}{|c|}{5.5} & \multicolumn{2}{|c|}{4.87} \\
\hline
\end{tabular}

${ }^{(1)}$ Means followed by equal letters, small in the columns and capital in the lines, do not differ by Tukey's test, at $5 \%$ probability. 
After cooking, the BRS 216 (small seed size) and BRS 267 cultivars showed the highest protein contents; the lowest content was observed in grains of the conventional soybean cultivar BRS 133, irrespective of raw or cooked. Raw grains of soybean cultivars did not present differences in lipid content and had a mean value of $192.47 \mathrm{~g} \mathrm{~kg}^{-1}$. The lowest lipid content in the cooked grains was observed in the BRS 267 cultivar, while BRS 258 showed the highest content. Sugar contents ranged from $343.80 \mathrm{~g} \mathrm{~kg}^{-1}$ (BRS 213) to $306.46 \mathrm{~g} \mathrm{~kg}^{-1}$ (BRS 258) in raw grains and, after cooking, from $320.53 \mathrm{~g} \mathrm{~kg}^{-1}$ (BRS 133) to $248.03 \mathrm{~g} \mathrm{~kg}^{-1}$ (BRS 258). No differences were observed between BRS 213 and BRS 133 cultivars regarding protein and lipid contents. Similar results were obtained by Ciabotti et al. (2006), indicating that the genetic elimination of the lipoxygenase enzymes in BRS 213 did not interfere in those constituents. Working with cultivars for human consumption, Vieira et al. (1999) observed variations of 385.60 to $419.50 \mathrm{~g} \mathrm{~kg}^{-1}$ for protein content; 222.40 to $238.00 \mathrm{~g} \mathrm{~kg}^{-1}$ for lipid content and 298.10 to $333.30 \mathrm{~g} \mathrm{~kg}^{-1}$ for the carbohydrates.

A decreased concentration of carbohydrates was observed after cooking, probably due to the solubilization of sugars in the soaking and cooking water, which increased protein and lipid contents. Giami (2002) observed that the highest carbohydrate content $\left(339 \mathrm{~g} \mathrm{~kg}^{-1}\right)$ after cooking was detected in soybean cultivars for human consumption. In soybean near-isogenic lines, Moraes et al. (2006) described variations in protein content from 406.8 to $477.8 \mathrm{~g} \mathrm{~kg}^{-1}$ and reported that the increasing of protein content was followed by the reduction of oil (from 167.1 to $207.8 \mathrm{~g} \mathrm{~kg}^{-1}$ ) and carbohydrates (from 300.1 to $336.1 \mathrm{~g} \mathrm{~kg}^{-1}$ ) contents. Differences observed in those studies can be attributed to the processing conditions of soybean grains but are mainly related to genetic differences among cultivars.

The lowest enzyme activity was observed in raw grains of the BRS 213 cultivar (Table 2), which

Table 2. Lipoxygenase activity ( $1 \mu \mathrm{mol}$ of linolenic acid hydroperoxide $\mathrm{min}^{-1}$ ) and hexanal $\left(\mu \mathrm{mol} \mathrm{mg} \mathrm{mg}^{-1}\right.$ ) content of raw and cooked soybean grains ${ }^{(1)}$.

\begin{tabular}{llllll}
\hline Cultivar & \multicolumn{2}{c}{ Lipoxygenase activity } & & \multicolumn{2}{c}{ Hexanal content } \\
\cline { 2 - 3 } \cline { 5 - 6 } & Raw & Cooked & & Raw & Cooked \\
\hline BRS 213 & $0.90 \mathrm{bA}$ & $0.35 \mathrm{bB}$ & & $15.19 \mathrm{bA}$ & $0.47 \mathrm{aB}$ \\
BRS 216 & $1.46 \mathrm{aA}$ & $0.79 \mathrm{aB}$ & & $12.66 \mathrm{cA}$ & $0.76 \mathrm{aB}$ \\
BRS 267 & $1.48 \mathrm{aA}$ & $0.36 \mathrm{bB}$ & & $7.46 \mathrm{dA}$ & $0.66 \mathrm{aB}$ \\
BRS 258 & $1.74 \mathrm{aA}$ & $0.72 \mathrm{abB}$ & & $17.27 \mathrm{aA}$ & $0.41 \mathrm{aB}$ \\
BRS 133 & $1.41 \mathrm{aA}$ & $0.54 \mathrm{abB}$ & & $17.45 \mathrm{aA}$ & $0.40 \mathrm{aB}$ \\
\hline CV $(\%)$ & \multicolumn{2}{c}{18.25} & & & 9.03 \\
\hline
\end{tabular}

${ }^{(1)}$ Means followed by equal letters, small in the columns and capital in the lines, do not differ by Tukey's test, at $5 \%$ probability. confirmed its special characteristics of absence of L1, L2 and L3 lipoxygenases. The residual value (0.90) observed for enzyme activity for this cultivar was probably due to the presence of other lipoxygenases (L4, L5 and L6), as described by Hildebrand (1996), or to waste metabolites from physiological post-harvest conditions. The other studied cultivars presented mean values equal to 1.5 and did not differ among each other. The cooking process reduced the enzyme activity and the smallest values were observed in the BRS 213, as expected, and BRS 267 cultivars. The results are similar to those observed by Nishiba et al. (1995), who reported reduced enzyme activity in null-lipoxygenase soybean cultivars and greater activity in conventional cultivars in comparison to the vegetable-type soybean.

The highest hexanal contents were observed in raw samples of the BRS 258 and BRS 133 conventional cultivars (Table 2). The results obtained in the present study are similar to those obtained by Nishiba et al. (1995), who reported that genetic differences for presence or absence of lipoxygenase among soybean cultivars can be observed in hexanal formation. However, an interesting result was observed in the raw grains of the vegetable-type cultivar (BRS 267), which presented the lowest hexanal content even with the presence of the lipoxygenase enzymes. This result is probably due to genetic characteristics of the vegetable-type cultivars, which present higher concentration of sucrose, glutamic acid and alanine contents (Masuda, 1991). The cooking process reduced the volatile compounds and no differences were observed among the cooked samples. The lipoxygenase enzymes are inactivated when the grains are soaked and cooked, resulting in similar outcomes for both the conventional cultivars (BRS 133 and BRS 258) and the null-lipoxygenase cultivar (BRS 213).

The highest total concentration of isoflavone glucosides was detected in raw and in cooked grains of BRS 267 cultivar, which did not differed from BRS 133 cooked grains, however(Table 3 ). The highest total malonyl-glucosides contents were detected in raw and cooked grains of the BRS 133 cultivar. The cooking process reduced the malonyl-glucosides contents due to the cleavage of malonyl esters groups to daidzin and genistin forms. Heat during cooking and during the later stages of the grain grinding and drying mechanisms can affect malonyl forms (Carrão-Panizzi, 1996). BRS 258 cultivar presented 
the lowest concentration of isoflavone glucosides and malonyl-glucosides. Carrão-Panizzi \& Kitamura (1995) reported reduced content of total isoflavones in BRS 36. This cultivar genetically originated BRS 258 (cross BR36*6 x Tracy-M). No differences were detected among cultivars (raw samples) for total aglycone contents. After cooking, BRS 267, the vegetable-type soybean cultivar, presented the highest aglycone content. This characteristic makes it a good source of bioavailable forms of isoflavones. Ciabotti et al. (2006) reported the following contents of isoflavones: BRS $133-0.75 \mathrm{~g} \mathrm{~kg}^{-1}$ of glucosides, $0.85 \mathrm{~g} \mathrm{~kg}^{-1}$ of malonyl-glucosides and $0.01 \mathrm{~g} \mathrm{~kg}^{-1}$ of aglycones; BRS $213-0.96 \mathrm{~g} \mathrm{~kg}^{-1}$ of glucosides, $1.19 \mathrm{~g} \mathrm{~kg}^{-1}$ of malonyl-glucosides and $0.04 \mathrm{~g} \mathrm{~kg}^{-1}$ of aglycones. The differences detected among isoflavone contents can be assigned to environmental conditions, and processing conditions of soybean grains (Aldin et al., 2006).

The presence of monosaccharide fructose in the raw soybean grains was not detected (Table 4). The highest sucrose content was observed in raw grains of BRS 267, the vegetable-type soybean cultivar. According to Masuda (1991), the mild and sweet flavor of vegetable-type cultivars are ascribed to the high sucrose content. After cooking, soybean cultivars did not differ in sucrose content. However, BRS 267 presented the highest content of fructose, what could also contribute to the sweet flavor of this material. The soybean cultivars for human consumption (BRS 216,
BRS 213 and BRS 267) presented higher amounts of raffinose in the raw material (9.18 $\mathrm{g} \mathrm{kg}^{-1}$, in average). Stachyose contents ranged from $35.36 \mathrm{~g} \mathrm{~kg}^{-1}$ for BRS 216 to $20.27 \mathrm{~g} \mathrm{~kg}^{-1}$ for BRS 267 in raw grains. Among cooked samples, the content ranged from $7.43 \mathrm{~g} \mathrm{~kg}^{-1}$ for BRS 216 to $3.56 \mathrm{~g} \mathrm{~kg}^{-1}$ for BRS 267. Reduced contents of sucrose, raffinose and stachyose, and presence of fructose in the cooked samples could be a response to sugar hydrolysis, which included water absorption during soaking and cooking at high temperature. Wang et al. (2007) also observed reduced contents of saccharides and oligosaccharides after soaking and cooking soybean grains.

The results of amino acids composition of cooked grains showed that the BRS 267 presents the highest content of glutamic acid and alanine (Table 5). Similar results were obtained by Masuda (1991), who observed that vegetable-type soybean cultivars presented the highest contents of glutamic acid and alanine. The most abundant amino acids were aspartic acid and glutamic acid, and the least abundant ones were tryptophan and methionine. These results are in agreement with Vieira et al. (1999).

The palmitic acid content in the raw grains ranged from $139.10 \mathrm{~g} \mathrm{~kg}^{-1}$ for the BRS 258 cultivar to $118.80 \mathrm{~g} \mathrm{~kg}^{-1}$ for the BRS 267 cultivar, and among cooked samples there were no differences (Table 6). Cultivars BRS 267 and BRS 258 presented the highest content of oleic acid, whereas after cooking the lowest contents were detected in the BRS 133 and BRS 216

Table 3. Isoflavone contents ( $\mathrm{g} \mathrm{kg}^{-1}$ dry weight) of raw and cooked soybean grains ${ }^{(1)}$.

\begin{tabular}{|c|c|c|c|c|c|c|}
\hline \multirow[t]{2}{*}{ Cultivar } & \multicolumn{2}{|c|}{ Glucosides } & \multicolumn{2}{|c|}{ Malonyl-glucosides } & \multicolumn{2}{|c|}{ Aglycones } \\
\hline & Raw & Cooked & Raw & Cooked & Raw & Cooked \\
\hline BRS 213 & $0.40 \mathrm{cB}$ & $0.69 \mathrm{bA}$ & $1.61 \mathrm{bA}$ & $0.78 \mathrm{bB}$ & $0.06 \mathrm{aA}$ & $0.06 \mathrm{cA}$ \\
\hline BRS 216 & $0.48 \mathrm{bcB}$ & $0.67 \mathrm{bA}$ & $1.72 \mathrm{bA}$ & $0.73 \mathrm{bB}$ & $0.04 \mathrm{aB}$ & $0.10 \mathrm{bcA}$ \\
\hline BRS 267 & $0.90 \mathrm{aA}$ & $0.88 \mathrm{aA}$ & $1.17 \mathrm{cA}$ & $0.76 \mathrm{bB}$ & $0.06 \mathrm{aB}$ & $0.47 \mathrm{aA}$ \\
\hline BRS 258 & $0.22 \mathrm{~dB}$ & $0.37 \mathrm{cA}$ & $0.73 \mathrm{dA}$ & $0.18 \mathrm{cB}$ & $0.02 \mathrm{aB}$ & $0.08 \mathrm{cA}$ \\
\hline BRS 133 & $0.54 \mathrm{bB}$ & $0.96 \mathrm{aA}$ & $2.03 \mathrm{aA}$ & $1.06 \mathrm{aB}$ & $0.04 \mathrm{aB}$ & $0.14 \mathrm{bA}$ \\
\hline CV (\%) & \multicolumn{2}{|c|}{6.82} & \multicolumn{2}{|c|}{5.98} & \multicolumn{2}{|c|}{20.43} \\
\hline
\end{tabular}

Table 4. Sugar contents ( $\mathrm{g} \mathrm{kg}^{-1}$ dry weight) of raw and cooked soybean grains ${ }^{(1)}$.

\begin{tabular}{|c|c|c|c|c|c|c|c|c|}
\hline \multirow[t]{2}{*}{ Cultivar } & \multicolumn{2}{|c|}{ Fructose } & \multicolumn{2}{|c|}{ Sucrose } & \multicolumn{2}{|c|}{ Raffinose } & \multicolumn{2}{|c|}{ Stachyose } \\
\hline & Raw & Cooked & Raw & Cooked & Raw & Cooked & Raw & Cooked \\
\hline BRS 213 & $0 \mathrm{aB}$ & $0.10 \mathrm{bcA}$ & $37.11 \mathrm{abA}$ & $9.02 \mathrm{aB}$ & $8.69 \mathrm{abA}$ & $1.57 \mathrm{abB}$ & $33.77 \mathrm{aA}$ & $6.45 \mathrm{aB}$ \\
\hline BRS 216 & $0 \mathrm{aB}$ & $0.10 \mathrm{bcA}$ & $41.81 \mathrm{abA}$ & $13.48 \mathrm{aB}$ & $9.26 \mathrm{aA}$ & $1.91 \mathrm{aB}$ & $35.36 \mathrm{aA}$ & $7.43 \mathrm{aB}$ \\
\hline BRS 267 & $0 \mathrm{aB}$ & $0.80 \mathrm{aA}$ & $43.50 \mathrm{aA}$ & $11.45 \mathrm{aB}$ & $9.59 \mathrm{aA}$ & $1.33 \mathrm{abB}$ & $20.27 \mathrm{cA}$ & $3.56 \mathrm{bB}$ \\
\hline BRS 258 & $0 \mathrm{aB}$ & $0.30 \mathrm{bA}$ & $34.06 \mathrm{bA}$ & $6.89 \mathrm{aB}$ & $7.51 \mathrm{bA}$ & 1.19abB & $32.52 \mathrm{abA}$ & $5.73 \mathrm{abB}$ \\
\hline BRS 133 & $0 \mathrm{aB}$ & $0.10 \mathrm{bcA}$ & $40.60 \mathrm{abA}$ & $11.45 \mathrm{aB}$ & $4.41 \mathrm{cA}$ & $0.93 \mathrm{bB}$ & $26.45 \mathrm{bcA}$ & 6.12abB \\
\hline CV (\%) & \multicolumn{2}{|c|}{26.84} & \multicolumn{2}{|c|}{12.54} & \multicolumn{2}{|c|}{6.28} & \multicolumn{2}{|c|}{5.79} \\
\hline
\end{tabular}

(1)Means followed by equal letters, small in the columns and capital in the lines, do not differ by Tukey's test, at $5 \%$ probability. 
cultivars. After cooking, BRS 267 also presented the highest content of oleic acid. This characteristic may contribute to the stability of the soybean oil during food processing (Fehr, 2007). Among raw samples, the content of linoleic acid ranged from $591.40 \mathrm{~g} \mathrm{~kg}^{-1}$ (BRS 216 cultivar) to $494.30 \mathrm{~g} \mathrm{~kg}^{-1}$ (BRS 258 cultivar). After cooking, grains of BRS 216 and BRS 133 cultivars had the highest contents of linoleic acid, while BRS 267 had the lowest content. The contents of linolenic acid among the raw grains ranged from $77.20 \mathrm{~g} \mathrm{~kg}^{-1}$ (BRS 213 cultivar) to $55.40 \mathrm{~g} \mathrm{~kg}^{-1}$ (BRS 267 cultivar). Kumar et al. (2006) also observed great variability for fatty acids concentrations among different soybean cultivars (96 to $145 \mathrm{~g} \mathrm{~kg}^{-1}$ for palmitic acid, 200 to $487 \mathrm{~g} \mathrm{~kg}^{-1}$ for oleic acid, 320 to $573 \mathrm{~g} \mathrm{~kg}^{-1}$ for linoleic acid and 42 to $100 \mathrm{~g} \mathrm{~kg}^{-1}$ for linolenic acid).

Grain sizes are defined by weight of 100 grains, which ranged from $10.40 \mathrm{~g}$ (BRS 216) to $24.92 \mathrm{~g}$ (BRS 267) (Table 7). At soaking treatments, BRS 133 cultivar grains presented the greatest water absorption capacity and the highest percentage of integral grains after cooking. Although the BRS 258 cultivar grains had high water absorption capacity during soaking, they presented lower percentage of whole grains after cooking, indicating that the higher degree of water absorption might interfere negatively in the grain integrity after heat treatment. Cooking time ranged from $31.35 \mathrm{~min}$ for BRS 213 to 47.20 min for BRS 258. Sharma et al. (2004) observed, in different soybean cultivars, variations of 106.1 to $133.1 \%$ for water absorption during soaking, of 58 to 66 minutes for cooking time, and of 8.5 to $11.6 \mathrm{~g}$ for weight of 100 grains. Vieira et al. (1997) worked with soybean cultivars for human consumption and reported differences of 15.31 and $19.76 \mathrm{~g}$ for weight of 100 grains, 132.54 and $125.67 \mathrm{~g}$ per $100 \mathrm{~g}$ for water absorption degree during soaking, and 155 to $219 \mathrm{~min}$ for cooking time.

The soybean cultivars for human consumption developed towards genetics breeding program at Embrapa Soja and analyzed in the present study can help processing soyfoods with better nutritional, functional and sensory properties: BRS 267 and BRS 216 cultivars can be used for the production of foods with superior nutritional value due to their high protein content; BRS 213 (low lipoxygenase activity) and BRS 267 (reduced hexanal content) can contribute to the development of soy products with reduced beany flavor. Cultivar BRS 267 also presents high oleic acid, sucrose, fructose, glutamic acid, alanine and aglicones contents. Because

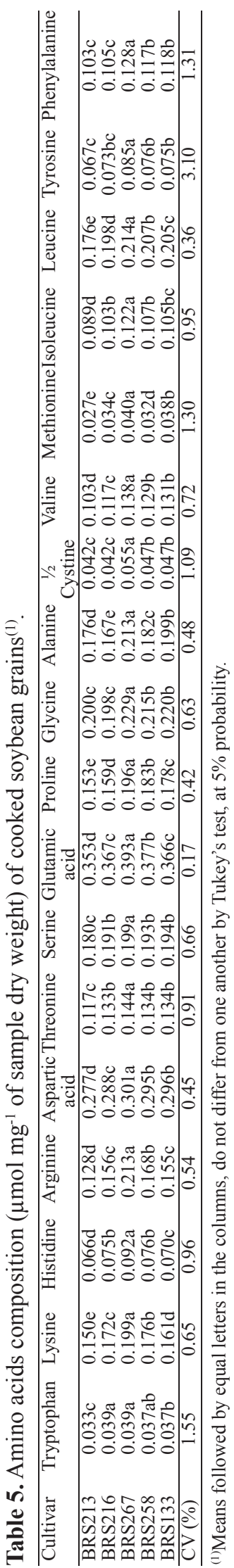


Table 6. Fatty acids content ( $\mathrm{g} \mathrm{kg}^{-1}$ dry weight) of raw and cooked soybean grains ${ }^{(1)}$.

\begin{tabular}{|c|c|c|c|c|c|c|c|c|}
\hline \multirow[t]{2}{*}{ Cultivar } & \multicolumn{2}{|c|}{ Palmitic acid } & \multicolumn{2}{|c|}{ Oleic acid } & \multicolumn{2}{|c|}{ Linoleic acid } & \multicolumn{2}{|c|}{ Linolenic acid } \\
\hline & Raw & Cooked & Raw & Cooked & Raw & Cooked & Raw & Cooked \\
\hline BRS 213 & $130.20 \mathrm{aA}$ & $124.30 \mathrm{aA}$ & $199.30 \mathrm{bA}$ & $207.40 \mathrm{bA}$ & $548.00 \mathrm{bA}$ & $539.40 \mathrm{bA}$ & $77.20 \mathrm{aA}$ & $79.10 \mathrm{bA}$ \\
\hline BRS 216 & $125.50 \mathrm{abA}$ & $124.40 \mathrm{aA}$ & $155.80 \mathrm{cB}$ & $170.30 \mathrm{cA}$ & $591.40 \mathrm{aA}$ & $573.70 \mathrm{aA}$ & $83.80 \mathrm{aA}$ & $88.30 \mathrm{abA}$ \\
\hline BRS 267 & $118.80 \mathrm{bB}$ & $130.70 \mathrm{aA}$ & $256.20 \mathrm{aA}$ & $258.60 \mathrm{aA}$ & $521.60 \mathrm{cA}$ & $490.60 \mathrm{cA}$ & $55.40 \mathrm{cB}$ & $70.90 \mathrm{bA}$ \\
\hline BRS 258 & $139.10 \mathrm{aA}$ & $132.80 \mathrm{aA}$ & $259.10 \mathrm{aA}$ & $201.30 \mathrm{bB}$ & $494.30 \mathrm{~dB}$ & $530.80 \mathrm{bA}$ & $64.30 \mathrm{bB}$ & $97.50 \mathrm{aA}$ \\
\hline BRS 133 & $132.00 \mathrm{aA}$ & $122.60 \mathrm{aA}$ & $197.00 \mathrm{bA}$ & $177.00 \mathrm{cB}$ & $552.20 \mathrm{bB}$ & $577.60 \mathrm{aA}$ & $71.10 \mathrm{abA}$ & $78.40 \mathrm{bB}$ \\
\hline CV $(\%)$ & \multicolumn{2}{|c|}{8.83} & \multicolumn{2}{|c|}{5.52} & \multicolumn{2}{|c|}{3.83} & \multicolumn{2}{|c|}{3.24} \\
\hline
\end{tabular}

${ }^{(1)}$ Means followed by equal letters, small in the columns and capital in the lines, do not differ by Tukey's test, at $5 \%$ probability.

Table 7. Weight (g), water absorption ( $\left(100 \mathrm{~g}^{-1}\right)$, cooking time (min) and whole grain integrity (\%) of raw soybean grains ${ }^{(1)}$.

\begin{tabular}{lcccc}
\hline Cultivar & Weight & Water absorption & Cooking time & Integrity \\
\hline BRS 213 & $16.50 \mathrm{~b}$ & $149.75 \mathrm{ab}$ & $31.35 \mathrm{c}$ & $85.47 \mathrm{ab}$ \\
BRS 216 & $10.40 \mathrm{c}$ & $153.41 \mathrm{ab}$ & $32.15 \mathrm{c}$ & $84.45 \mathrm{~b}$ \\
BRS 267 & $24.92 \mathrm{a}$ & $138.73 \mathrm{~b}$ & $41.76 \mathrm{ab}$ & $88.52 \mathrm{ab}$ \\
BRS 258 & $16.00 \mathrm{~b}$ & $155.11 \mathrm{ab}$ & $47.20 \mathrm{a}$ & $61.45 \mathrm{c}$ \\
BRS 133 & $16.00 \mathrm{~b}$ & $155.80 \mathrm{a}$ & $41.95 \mathrm{ab}$ & $94.70 \mathrm{a}$ \\
\hline CV (\%) & 1.75 & 3.75 & 9.63 & 4.53 \\
\hline
\end{tabular}

(1) Means followed by equal letters in the columns do not differ by Tukey's test, at $5 \%$ probability.

of all these characteristics, the BRS 267 cultivar is one of the best sources of raw material for soy food products. Its larger grain size makes it proper material for tofu salads or green vegetable soybeans. BRS 216, a unique soybean cultivar with small seed size, is important for the production of natto and soybean sprouts. BRS 213 and BRS 216 presented shorter cooking time, which would allow reducing industrial processing costs. BRS 133 and BRS 258, as all other conventional soybean cultivars, are suitable for oil and animal feeding.

\section{Conclusion}

1. The food-type soybean cultivar BRS 213, which has null lipoxygenase enzymes, can improve the flavor of soyfood products.

2. The food-type soybean cultivar BRS 267 is the best raw material for soyfood processing, and it is indicated for tofu, soy milk, soy flour and vegetable green soybeans.

3. The food-type soybean cultivar BRS 216 , which has small seed size, is proper for the production of natto and soybean sprouts.

4. The grain-type soybean cultivars BRS 133 and BRS 258 are suitable for oil processing and animal feeding.

\section{References}

ALDIN, E.; REITMEIER, C.A.; MURPHY, P. Bitterness of soy extracts containing isoflavones and saponins. Journal of Food Science, v.71, p.211-215, 2006.

ALONZO, N.; HIRS, C.H.W. Automation of sample application in amino acid analyzers. Analytical Biochemistry, v.23, p.272-288, 1968.

AXEROLD, B.; CHEESBROUGHT, T.M.; LAAKSO, S. Lipoxygenase from soybean. Methods Enzymologics, v.71, p.441-451, 1981.

BERHOW, M.A. Modern analytical techniques for flavonoid determination. In: BUSLIG, B.S.; MANTHEY, J.A. (Ed.). Flavonoids in cell function. New York: Klusher Academic, 2002. p.61-76.

CARRÃO-PANIZZI, M.C. Avaliação de cultivares de soja quanto aos teores de isoflavonóides. Pesquisa Agropecuária Brasileira, v.31, p.691-698, 1996.

CARRÃO-PANIZZI, M.C. Melhoramento genético da soja para a obtenção de cultivares mais adequadas ao consumo humano. Revista Brasileira de Nutrição Clínica, v.15, p.330-340, 2000.

CARRÃO-PANIZZI, M.C.; FAVONI, S.P.G.; KIKUCHI, A. Extraction time for soybean isoflavone determination. Brazilian Archives of Biology and Technology, v.45, p.515-518, 2002.

CARRÃO-PANIZZI, M.C.; KITAMURA, K. Isoflavone content in Brazilian soybean cultivars. Breeding Science, v.45, p.295-300, 1995.

CIABOTTI, S.; BARCELlOS, M. de F.P.; MANDARINO, J.M.G.; TARONE, A.G. Avaliações químicas e bioquímicas dos grãos, extratos e tofus de soja comum e de soja livre de lipoxigenase. Ciência Agrotécnica, v.30, p.920-929, 2006.

FEHR, W.R. Breeding for modified fatty acid composition in soybean. Crop Science, v.47, p.72-87, 2007.

FURUTA, S.; NISHIBA, V.; HAJIKA, M.; IGITA, K.; SUDA, I. DETBA value and hexanal production with the combination of unsaturated fatty acids and extracts prepared from soybean seeds lacking two or three lipoxygenase isozymes. Journal of Agricultural and Food Chemistry, v.44, p.236-239, 1996.

GIAMI, S.Y. Chemical composition and nutritional attributes of selected newly developed lines of soybean (Glycine max (L) Merr). Journal of the Science of Food and Agriculture, v.82, p.1735-1739, 2002. 
HILDEBRAND, D. Genetics of soybean lipoxygenases. In: PIAZZA, G. (Ed.). Lipoxygenase and lipoxygenase pathway enzymes. Illinois: AOCS Press, 1996. p.33-38.

INSTITUTO ADOLFO LUTZ. Métodos físico-químicos para análise de alimentos. São Paulo: Instituto Adolfo Lutz, 2005. $1018 \mathrm{p}$.

KUMAR, V.; RANI, A.; SOLANKI, S.; HUSSAIN, S.M. Influence of growing environment on the biochemical composition and physical characteristics of soybean seed. Journal of Food Composition and Analysis, v.19, p.188-195, 2006.

LIU, K. Soybeans: chemistry, technology and utilization. New York: Klewer Academic, 1999. 532p.

MASUDA, R. Quality requirement and improvement of vegetable soybean. In: WORKSHOP HEALD, 1991, Kenting. Vegetable soybean: research needs for production and quality improvement: proceedings. Taipei: AVRDC, 1991. p.92-102. (AVRDC. Publication, 91-346).

MASUDA, R.; KANEKO, K.; YAMASHITA, I. Sugar and cyclitol determination in vegetables by HPLC using postcolumn fluorescent derivatization. Journal of Food Science, v.61, p.1186-1190, 1996.

MENEGUCE, B.; FARIA, R.T.; DESTRO, D.; FONSECA JÚNIOR, N.S.; FARIA, A.P. Interação genótipo $\mathrm{x}$ ano para tempo de cozimento e sua correlação com a massa e percentagem de embebição em soja tipo alimento. Semina: Ciências Agrárias, v.26, p.463-476, 2005.

MIN, S.; YU, Y.; YOO, S.; MARTIN, S.S. Effect of soybean varieties and growing locations on the flavor of soymilk. Journal of Food Science, v.70, p.1-7, 2005.

MORAES, R.M.A. de; JOSÉ, I.C.; RAMOS, F.G.; BARROS, E.G. de; MOREIRA, M.A. Caracterização bioquímica de linhagens de soja com alto teor de proteína. Pesquisa Agropecuária Brasileira, v.41, p.725-729, 2006.

NISHIBA, Y.; FURUTA, S.; HAJIKA, M.; IGITA, K.; SUDA, I. Hexanal accumulation and DETBA value in homogenate of soybean seeds lacking two or three lipoxygenase isozymes. Journal of Agricultural and Food Chemistry, v.43, p.738-741, 1995.

RAYFORD, W.E.; THOMAS, D.I.; ELAM, L.M.; WALKER, S.M. Analytical chemical support soybean uniform test analysis. Peoria: United States Department of Agriculture, 1994. p.17-26.

SAS INSTITUTE. SAS user's guide: statistics. Version 8.2. Cary: SAS Institute, 2001.

SBARDELOTTO, A.; LEANDRO, G.V. Escolha de cultivares de soja com base na composição química dos grãos como perspectiva para maximização dos lucros nas indústrias processadoras. Ciência Rural, v.38, p.614-619, 2008.

SHARMA, S.; SAXENA, A.K.; DHILLON, S.K. Physico-chemical and cooking quality characteristics of soybean (Glycine max). Journal of Food Science and Technology-Mysore, v.41, p.554-556, 2004.

SPACKMAN, D.H.; STEIN, W.H.; MOORE, S. Automatic recording apparatus for use in the chromatography of amino acids. Analytical Chemistry, v.30, p.1190-206, 1958.

TOMOMATSU, H. Health effects of oligosaccharides. Food Technology, v.10, p.61-65, 1994.

VIEIRA, C.R.; CABRAL, L.C.; PAULA, A.C.O. de. Caracterização física e tecnológica de seis cultivares de soja plantadas no Brasil.

Ciência e Tecnologia de Alimentos, v.17, p.291-294, 1997.

VIEIRA, C.R.; CABRAL, L.C.; PAULA, A.C.O. de. Composição centesimal e conteúdo de aminoácidos, ácidos graxos e minerais de seis cultivares de soja destinadas à alimentação humana. Pesquisa Agropecuária Brasileira, v.34, p.1277-1283, 1999.

WANG, Q.S.; KE, L.Q.; YANG, D.M.; BAO, B.L.; YING, T.J. Change in oligosaccharides during processing of soybean sheet. Asia Pacific Journal of Clinical Nutrition, v.16, p.89-94, 2007.

ZONTA, E.P.; MACHADO, A.A.; SILVEIRA JÚNIOR, P. Sistema de análise estatística. Pelotas: UFPEL, 1982. 63p.

Received on March 2, 2009 and accepted on June 28, 2009 